\title{
STÉPHANE GOUGELMANN, Jules Renard, écrivain de
}

\section{l'intime}

Ida Merello

\section{OpenEdition}

\section{Journals}

\section{Edizione digitale}

URL: https://journals.openedition.org/studifrancesi/12020

DOI: 10.4000/studifrancesi. 12020

ISSN: 2421-5856

\section{Editore}

Rosenberg \& Sellier

\section{Edizione cartacea}

Data di pubblicazione: 1 avril 2018

Paginazione: 160

ISSN: 0039-2944

\section{Notizia bibliografica digitale}

Ida Merello, «stéphane gougelmann, Jules Renard, écrivain de l'intime», Studi Francesi [Online], 184 (LXII | I) | 2018, online dal 03 juillet 2018, consultato il 17 novembre 2021. URL: http://journals.openedition.org/ studifrancesi/12020 ; DOI: https://doi.org/10.4000/studifrancesi.12020

Questo documento è stato generato automaticamente il 17 novembre 2021.

\section{@(๑) $\Theta \Theta$}

Studi Francesi è distribuita con Licenza Creative Commons Attribuzione - Non commerciale - Non opere derivate 4.0 Internazionale. 


\title{
STÉPHANE GOUGELMANN, Jules Renard, écrivain de l'intime
}

\author{
Ida Merello
}

\section{NOTIZIA}

StÉPHANe GougelmanN, Jules Renard, écrivain de l'intime, Paris, Classiques Garnier 2017, 686 pp.

1 Il volume, molto corposo, e corredato da ampia bibliografia, si inserisce nel solco degli studi sulla natura e gli scopi della vocazione autobiografica in Jules Renard, intrapresi da Léon Guichard, che aveva curato l'edizione Pléiade del Journal nel 1965 e prima ancora da Pierre Nardin (La langue et le style de J.R., 1957). A sua volta il lavoro giunge a coronamento di un lungo percorso critico dell'A., interamente votato a Renard. Si tratta di uno studio molto limpido e approfondito, introdotto da un'analisi delle prime opere renardiane, dove l'Ecornifleur è riconosciuto come il romanzo cerniera tra il realismo iniziale e la scelta di una scrittura che evoca l'autobiografia sotto tutte le forme. È nel ventaglio di queste che l'A. spazia, per mostrare come in Renard il materiale autobiografico sia considerato l'elemento indispensabile per un'opera che non insegue solo esiti estetici ma costituisce insieme una quête e un tentativo quasi terapeutico di ricavare delle fleurs dal male che la situazione biografica ha riversato su di lui. L'opera renardiana si configura come un andirivieni fra finzione e autobiografia anche nello spazio del Journal, e l'A. interroga le modalità di questa dialettica e le sue ragioni. 